\title{
OPTIMALISASI MASALAH PENUGASAN TIDAK SEIMBANG MENGGUNAKAN MODIFIED HUNGARIAN METHOD
}

\author{
Renaldo Evipania $^{1 \S}$, G. K. Gandhiadi² ${ }^{2}$ I Wayan Sumarjaya ${ }^{3}$ \\ ${ }^{1}$ Program Studi Matematika, Fakultas MIPA - Universitas Udayana [Email: renaldo.evipania@gmail.com] \\ ${ }^{2}$ Program Studi Matematika, Fakultas MIPA - Universitas Udayana [Email: gandhiadi@unud.ac.id] \\ ${ }^{3}$ Program Studi Matematika, Fakultas MIPA - Universitas Udayana [Email: sumarjaya@gmail.com] \\ ${ }^{\S}$ Corresponding Author
}

\begin{abstract}
Assignment problem is one of the cases that found in linear programming. Assignment problem is related to the allocation of workers for available jobs. From several sources, Hungarian method is more often used to solve the assignment problem. In the Hungarian method, if an unbalanced problem is found, the lack of the source or destination will be added to the dummy variable so that the case becomes balanced. The jobs that executed on the dummy machine will be ignored. In real-life situations, it is impossible for companies to ignore existing work because of a lack of workers. Therefore, the Hungarian method is modified to resolve this condition, so that the total assignment cost can still be optimized.
\end{abstract}

Keywords: Linear Programming, Unbalanced Assignment Problems, Modified Hungarian Method.

\section{PENDAHULUAN}

Pemrograman linear adalah salah satu bagian yang dibahas dalam riset operasi. Pemrograman linear merupakan metode matematika untuk mengalokasikan sumber daya yang terbatas, sehingga mencapai suatu tujuan tertentu seperti meminimalkan biaya produksi atau memaksimalkan keuntungan. Dalam suatu perusahaan atau industri, sumber daya terbatas tersebut meliputi semua faktor produksi, seperti mesin-mesin, tenaga kerja, bahan mentah, ataupun modal (Syaifuddin, 2011).

Masalah penugasan atau assignment problem merupakan kasus khusus dari model transportasi, dimana beberapa jumlah $m$ sumber akan diberikan kepada $n$ tujuan (satu sumber hanya untuk satu tujuan, begitu sebaliknya) sehingga didapati total biaya minimumnya. Sumber yang dimaksud dalam pernyataan diatas biasanya berupa pekerja (atau jenis pekerjaan), sedangkan tujuannya adalah mesin. Pada kasus ini, akan ada $m$ pekerjaan yang diberikan kepada $n$ mesin, dimana $i(i=$ $1,2,3, \ldots, m)$ sebagai pekerja atau pekerjaan yang ditugaskan kepada $j(j=1,2,3, \ldots, n)$ sebagai mesin yang ada sehingga akan diperoleh $c_{i j}$ sebagai total biaya penugasan. Karena hanya ada satu pekerjaan yang akan ditugaskan pada satu mesin, maka supply atau masukan yang digunakan untuk masing-masing sumber yang ada adalah 1 (atau $a_{i}=1$ untuk seluruh $i$ ). Demikian pula halnya dengan mesin, karena satu mesin hanya dapat menerima satu jenis pekerjaan saja, maka demand atau permintaan dari setiap tujuan adalah 1 (atau $b_{j}=1$ untuk seluruh $j$ ). (Taha, 1997). Masalah penugasan dapat dipecahkan dengan beberapa metode, antara lain: metode simpleks, metode Brute Force, metode pinalti, metode Hungaria, dan metode transportasi.

Metode Hungaria ditemukan pertama kali pada tahun 1955 oleh Harold Kuhn. Kemudian dikembangkan oleh James Munkers pada tahun 1957 yang kemudian dikenal sebagai algoritme Kuhn-Munkers. Algoritme ini kemudian dikembangkan lagi oleh dua orang ahli matematika berkebangsaan Hungaria yang bernama D. Konig dan J. Egervary. Kelebihan metode Hungaria dalam memecahkan masalah penugasan dibandingkan dengan metode 
lainnya terdapat pada efisiensi dari segi proses iterasinya. Masalah penugasan tersebut mampu disederhanakan dengan memformulasikannya terlebih dahulu ke dalam bentuk matriks, dimana kolom menunjukkan tujuan dan baris menunjukkan sumber atau sebaliknya.

Penelitian tentang metode Hungaria pernah dilakukan sebelumnya oleh Harini (2017) pada CV. L\&J Express Malang sebagai unit usaha di bidang pelayanan pengiriman barang. Pada penelitian tersebut, dicari waktu optimal pengiriman barang agar tepat atau sesuai dengan tujuan pengiriman. Kesimpulan dari penelitian tersebut adalah pengalokasian enam karyawan pada enam lokasi yang berbeda sebelum menggunakan metode Hungaria membutuhkan waktu sebanyak 119 menit. Setelah menggunakan metode Hungaria, waktu yang dibutuhkan berubah menjadi 105 menit. Terjadi efisiensi atau penghematan waktu perjalanan mengantarkan barang sebesar 14 menit.

Mitra Tex Konveksi adalah salah satu industri konveksi pakaian yang berada di Jl. Kampus Udayana Jimbaran, Bali. Masalah penugasan yang terjadi pada Mitra Tex Konveksi adalah masalah penugasan tidak seimbang dimana jumlah karyawan lebih sedikit dibandingkan jumlah pekerjaan yang ada. Pada metode Hungaria, apabila dijumpai masalah tidak seimbang, kekurangan sumber atau tujuan tersebut akan ditambahkan variabel dummy sehingga kasusnya menjadi seimbang. Pekerjaan yang dieksekusi pada mesin dummy akan diabaikan. Pada situasi kehidupan nyata, tidak mungkin perusahaan mengabaikan pekerjaan yang ada karena kurangnya pekerja, maka metode Hungaria dimodifikasi untuk menyelesaikan kondisi ini, sehingga total biaya penugasan tetap dapat dioptimalkan.

Oleh karena itu, perlu dilakukan pemecahan masalah penugasan tidak seimbang pada karyawan Mitra Tex Konveksi dengan menggunakan metode Hungaria yang dimodifikasi untuk mendapatkan hasil solusi optimal waktu pengoperasiannya.

\section{METODE PENELITIAN}

Data kuantitatif yang dimiliki perusahaan pada periode Juli 2020 merupakan data yang digunakan dalam penelitian ini. Data tersebut berupa estimasi waktu yang dibutuhkan untuk menyelesaikan setiap jenis pakaian oleh masing-masing karyawan di setiap penugasannya Berdasarkan hal tersebut, tujuan dari penelitian ini adalah mengetahui hasil optimal masalah penugasan tidak seimbang dilihat dari waktu yang dibutuhkan pekerja untuk menyelesaikan semua jenis pekerjaan yang ada menggunakan Modified Hungarian Method. Adapun pekerja yang ada di perusahaan tersebut terdiri dari lima orang, yaitu Pak Andy, Bu Lily, Pak Eddy, Pak Surya, dan Pak Adit, dengan delapan jenis pekerjaan sebagai berikut:

1. Jas

2. Kaos Polo

3. Jaket

4. Seragam Pakaian Dinas Harian (PDH)

5. Kemeja

6. Kain Bermotif Batik

7. Celana Jeans

8. Celana Bahan

Langkah-langkah yang dilakukan dalam penelitian ini adalah sebagai berikut:

1. Menghitung rata-rata waktu pengerjaan (jam/set) setiap barang yang dihasilkan oleh setiap karyawan.

2. Membentuk fungsi tujuan dan fungsi kendalanya.

3. Mencari waktu optimal dengan meminimalkan waktu yang dibutuhkan pekerja untuk menyelesaikan pekerjaannya dengan langkah-langkah metode Hungarian sebagai berikut:

a) Menyusun tabel atau matriks penugasan

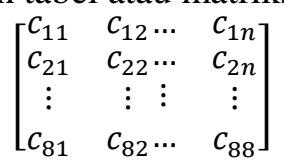

b) Memilih biaya terendah pada setiap baris yang ada. Kemudian kurangkan biaya terendah dalam tiap baris pada tabel biaya tertentu dari semua biaya dalam baris tersebut.

c) Memilih biaya terendah pada setiap kolom yang ada, kemudian kurangkan biaya terendah dalam tiap kolom tabel yang diperoleh dari langkah a terhadap semua biaya dalam kolom tersebut.

d) Menentukan apakah solusi penugasan optimal dapat dibuat dengan cara menarik garis horizontal atau vertikal terhadap tabel total biaya kesempatan sedemikian rupa guna meminimumkaan jumlah garis yang melintasi semua elemen nol. Suatu penugasan optimal dapat dibuat bila jumlah garis sama dengan jumlah baris. Bila jumlah garis 
yang dapat dibuat lebih sedikit dari jumlah baris, maka penugasan optimal tidak dapat dibuat dan persoalan tidak dapat dipecahkan.

e) Memperbaiki atau merevisi tabel total biaya kesempatan dengan cara memilih angka terkecil dalam tabel yang tidak dilalui garis lurus dan kurangkan angka ini dari semua angka yang tidak dilalui oleh garis lurus Setelah itu, tambahkan angka yang sama pada perpotongan antara dua garis dan kembali ke Langkah d. (Aminudin, 2005)

4 Menemukan hasil solusi optimal masingmasing matriks keseimbangan, kemudian jumlahkan untuk memperoleh total waktu optimal.

5 Jika hasil telah optimal, lakukan pembagian atau pengalokasian tugas dilihat dari segi waktu yang paling optimal.

6 Interpretasi hasil secara teoretis dan realistis.

Untuk Modified Hungarian Method, letak modifikasinya terletak setelah langkah kedua, yaitu mempartisi matriks untuk memperoleh keseimbangan matriks. Keseimbangan matriks akan dicapai apabila jumlah pekerja sudah sama dengan jumlah pekerjaan yang ada. Adapun cara pertama yang dilakukan untuk mempartisi matriks adalah menjumlahkan setiap baris dan setiap kolom untuk memperoleh urutan partisi. Urutan partisi diperoleh dari menjumlahkan semua elemen baik di kolom maupun baris. Untuk total penjumlahan pada kolom akan disimpan hasilnya ke dalam Sum_Column dan untuk baris akan disimpan hasilnya ke dalam Sum_Row (Rabbani, 2019).

\section{HASIL DAN PEMBAHASAN}

Data yang diperoleh dari Mitra Tex Konveksi berupa rata-rata waktu penyelesaian yang dibutuhkan masing-masing pekerja untuk mengerjakan setiap jenis pakaian yang ada. Waktu penyelesaian tersebut dihitung dari tahap pembuatan pola, pemotongan bahan, sampai dengan menjahit. Data tersebut dapat dilihat pada tabel penugasan berikut:
Tabel 1. Data Penugasan Mitra Tex Konveksi

\begin{tabular}{|c|c|c|c|c|c|c|c|c|}
\hline \multirow{2}{*}{$\begin{array}{c}\text { Peker } \\
\text { ja }\end{array}$} & \multicolumn{7}{|c|}{ Lama Penyelesaian Pekerjaan (jam) } \\
\cline { 2 - 9 } & I & II & III & IV & V & VI & VII & VIII \\
\hline 1 & 7 & 3 & 3.5 & 4 & 5 & 4 & 3 & 2 \\
\hline 2 & 5 & 2.5 & 4 & 4 & 4 & 4 & 2 & 2 \\
\hline 3 & 7 & 3 & 3 & 4.5 & 5 & 4 & 2.5 & 2 \\
\hline 4 & 5 & 2 & 3.5 & 3 & 3 & 3 & 2.5 & 2 \\
\hline 5 & 6 & 3 & 4 & 4 & 3 & 2 & 2 & 1.5 \\
\hline
\end{tabular}

Sebelum menggunakan metode Hungaria, waktu yang dibutuhkan karyawan Mitra Tex Konveksi untuk menyelesaikan setiap jenis pekerjaan yang ada disajikan pada Tabel 2 sebagai berikut:

Tabel 2. Total waktu yang diperlukan dalam proses produksi sebelum menggunakan metode Hungarian

\begin{tabular}{|l|c|}
\hline Jenis Pekerjaan (set) & $\begin{array}{l}\text { Lama Penyelesaian } \\
\text { (jam) }\end{array}$ \\
\hline Jas & 6 \\
\hline Kaos Polo & 2.7 \\
\hline Jaket & 3.6 \\
\hline Seragam PDH & 3.9 \\
\hline Kemeja & 4 \\
\hline Kain Bermotif Batik & 3.4 \\
\hline Celana Jeans & 2.4 \\
\hline Celana Kain & 1.9 \\
\hline Total waktu & 27.9 \\
\hline
\end{tabular}

Berdasarkan Tabel 1, bentuk matriks penugasannya adalah sebagai berikut:

$\left[\begin{array}{ccccccccc} & \text { I } & \text { II } & \text { III } & \text { IV } & \text { V } & \text { VI } & \text { VII } & \text { VIII } \\ \mathrm{P}_{1} & 7 & 3 & 3.5 & 4 & 5 & 4 & 3 & 2 \\ \mathrm{P}_{2} & 5 & 2.5 & 4 & 4 & 4 & 4 & 2 & 2 \\ \mathrm{P}_{3} & 7 & 3 & 3 & 4.5 & 5 & 4 & 2.5 & 2 \\ \mathrm{P}_{4} & 5 & 2 & 3.5 & 3 & 3 & 3 & 2.5 & 2 \\ \mathrm{P}_{5} & 6 & 3 & 4 & 4 & 3 & 2 & 2 & 1.5\end{array}\right]$

Karena jumlah pekerja dan jenis pekerjaan tidak sama, maka permasalahan ini dikatakan tidak seimbang. Oleh karena itu, matriks di atas perlu dipartisi agar seimbang. Adapun cara pertama yang dilakukan untuk mempartisi matriks adalah menjumlahkan setiap baris dan setiap kolom untuk memperoleh urutan partisi. Urutan partisi diperoleh dari menjumlahkan semua elemen baik di kolom maupun baris. Untuk total penjumlahan pada kolom akan disimpan hasilnya ke dalam Sum_Column ( ) dan untuk baris akan disimpan hasilnya ke dalam Sum_Row ( ) sebagai berikut: 
Sum_Column ()$=$

$\begin{array}{cccccccc}\text { I } & \text { II } & \text { III } & \text { IV } & \text { V } & \text { VI } & \text { VII } & \text { VIII } \\ 30 & 13.5 & 18 & 19.5 & 20 & 17 & 12 & 9.5 \\ \text { Sum_Row } & ()= & & & & & \\ \mathrm{P}_{1} & \mathrm{P}_{2} & \mathrm{P}_{3} & \mathrm{P}_{4} & \mathrm{P}_{5} & & & \\ 31.5 & 27.5 & 31 & 24 & 25.5 & & & \end{array}$

Setelah itu, urutkan dari yang paling kecil yang paling besar, sehingga diperoleh seperti berikut:

Sum_Column: VIII, VII, II, VI, III, IV, V, I.

Sum_Row: $\mathrm{P}_{4}, \mathrm{P}_{5}, \mathrm{P}_{2}, \mathrm{P}_{3}, \mathrm{P}_{1}$.

Setelah mendapatkan urutan, partisi matriks diatas menjadi $A_{1}$ untuk mendefinisikan matriks keseimbangan pertama dan $A_{2}$ untuk mendefinisikan matriks keseimbangan kedua sehingga diperoleh:

$\mathrm{A}_{1}=\left[\begin{array}{cccccc} & \text { II } & \text { III } & \text { VI } & \text { VII } & \text { VIII } \\ \mathrm{P}_{1} & 3 & 3.5 & 4 & 3 & 2 \\ \mathrm{P}_{2} & 2.5 & 4 & 4 & 2 & 2 \\ \mathrm{P}_{3} & 3 & 3 & 4 & 2.5 & 2 \\ \mathrm{P}_{4} & 2 & 3.5 & 3 & 2.5 & 2 \\ \mathrm{P}_{5} & 3 & 4 & 2 & 2 & 1.5\end{array}\right]$

$A_{2}=\left[\begin{array}{cccc} & \text { I } & \text { IV } & \text { V } \\ \mathrm{P}_{2} & 5 & 4 & 4 \\ \mathrm{P}_{4} & 5 & 3 & 3 \\ \mathrm{P}_{5} & 6 & 4 & 3\end{array}\right]$

Kemudian, menyelesaikan masing-masing matriks keseimbangan dengan metode Hungaria:

$\mathrm{A}_{1}=\left[\begin{array}{cccccc} & \text { II } & \text { III } & \text { VI } & \text { VII } & \text { VIII } \\ \mathrm{P}_{1} & 3 & 3.5 & 4 & 3 & 2 \\ \mathrm{P}_{2} & 2.5 & 4 & 4 & 2 & 2 \\ \mathrm{P}_{3} & 3 & 3 & 4 & 2.5 & 2 \\ \mathrm{P}_{4} & 2 & 3.5 & 3 & 2.5 & 2 \\ \mathrm{P}_{5} & 3 & 4 & 2 & 2 & 1.5\end{array}\right]$

Memilih nilai terkecil pada setiap baris. Nilai terkecil pada setiap baris dari matriks $\mathrm{A}_{1}$ adalah sebagai berikut:

$$
\mathrm{A}_{1}=\left[\begin{array}{cccccc} 
& \text { II } & \text { III } & \text { VI } & \text { VII } & \text { VIII } \\
\mathrm{P}_{1} & 3 & 3.5 & 4 & 3 & 2 \\
\mathrm{P}_{2} & 2.5 & 4 & 4 & 2 & 2 \\
\mathrm{P}_{3} & 3 & 3 & 4 & 2.5 & 2 \\
\mathrm{P}_{4} & 2 & 3.5 & 3 & 2.5 & 2 \\
\mathrm{P}_{5} & 3 & 4 & 2 & 2 & 1.5
\end{array}\right]
$$

Kemudian, lakukan operasi pengurangan di tiap nilai pada baris tersebut dengan nilai terkecil yang telah dipilih sehingga dapat dipastikan bahwa akan ada minimal satu buah elemen di tiap baris matriks yang nilainya nol dan tidak ada elemen yang bernilai negatif.

$$
\mathrm{A}_{1}=\left[\begin{array}{cccccc} 
& \text { II } & \text { III } & \text { VI } & \text { VII } & \text { VIII } \\
\mathrm{P}_{1} & 1 & 1.5 & 2 & 1 & 0 \\
\mathrm{P}_{2} & 0.5 & 2 & 2 & 0 & 0 \\
\mathrm{P}_{3} & 1 & 1 & 2 & 0.5 & 0 \\
\mathrm{P}_{4} & 0 & 1.5 & 1 & 0.5 & 0 \\
\mathrm{P}_{5} & 1.5 & 2.5 & 0.5 & 0.5 & 0
\end{array}\right]
$$

Memeriksa kolom. Apabila masih terdapat kolom yang belum memiliki nilai nol, kurangkan semua nilai elemen pada kolom tersebut dengan nilai elemen terkecil yang ada pada kolom yang bersangkutan.

$$
\mathrm{A}_{1}=\left[\begin{array}{cccccc} 
& \text { II } & \text { III } & \text { VI } & \text { VII } & \text { VIII } \\
\mathrm{P}_{1} & 1 & 1.5 & 2 & 1 & 0 \\
\mathrm{P}_{2} & 0.5 & 2 & 2 & 0 & 0 \\
\mathrm{P}_{3} & 1 & 1 & 2 & 0.5 & 0 \\
\mathrm{P}_{4} & 0 & 1.5 & 1 & 0.5 & 0 \\
\mathrm{P}_{5} & 1.5 & 2.5 & 0.5 & 0.5 & 0
\end{array}\right]
$$

Setelah diperiksa, ternyata matriks pada langkah 2 menunjukkan bahwa kolom III, dan VI masih belum terdapat nilai 0. Oleh karena itu, semua nilai yang ada pada kolom tersebut akan dikurangi dengan nilai elemen terkecil pada kolom tersebut, yaitu 0.5. Sehingga diperoleh:

$$
\mathrm{A}_{1}=\left[\begin{array}{cccccc} 
& \text { II } & \text { III } & \text { VI } & \text { VII } & \text { VIII } \\
\mathrm{P}_{1} & 1 & 1 & 1.5 & 1 & 0 \\
\mathrm{P}_{2} & 0.5 & 1.5 & 1.5 & 0 & 0 \\
\mathrm{P}_{3} & 1 & 0.5 & 1.5 & 0.5 & 0 \\
\mathrm{P}_{4} & 0 & 1 & 0.5 & 0.5 & 0 \\
\mathrm{P}_{5} & 1.5 & 2 & 0 & 0.5 & 0
\end{array}\right]
$$

Memeriksa apakah solusi penugasan sudah optimal atau belum. Caranya dengan menarik sejumlah garis horizontal atau vertikal yang melewati seluruh sel yang bernilai 0 . Apabila jumlah garis yang terbentuk sudah sama dengan jumlah kolom atau baris yang ada, maka penugasan dapat dikatakan sudah optimal. Jika belum sama, maka wajib dilakukan revisi atau perbaikan tabel.

$$
\mathrm{A}_{1}=\left[\begin{array}{cccccc} 
& \text { II } & \text { III } & \text { VI } & \text { VII } & \text { VIII } \\
\mathrm{P}_{1} & 1 & 1 & 1.5 & 1 & 0 \\
\mathrm{P}_{2} & 0.5 & 1.5 & 1.5 & 0 & 0 \\
\mathrm{P}_{3} & 1 & 0.5 & 1.5 & 0.5 & 0 \\
\mathrm{P}_{4} & 0 & 1 & 0.5 & 0.5 & 0 \\
\mathrm{P}_{5} & 1.5 & 2 & 0 & 0.5 & 0
\end{array}\right]
$$

Setelah ditarik garis seminimal mungkin, diperoleh bahwa banyaknya garis yang terbentuk hanya sebanyak empat garis sedangkan, jumlah garis yang terbentuk seharusnya sebanyak lima garis. Karena 
jumlah garis yang terbentuk belum sama dengan jumlah baris/kolom, solusi belum bisa dikatakan optimal. Oleh karena itu, akan dilanjutkan ke langkah berikutnya.

Melakukan revisi tabel dengan cara memilih nilai terkecil pada sel yang tidak dilewati garis. Adapun nilai elemen terkecil yang terletak di luar garis adalah 2.

$$
\mathrm{A}_{1}=\left[\begin{array}{cccccc} 
& \text { II } & \text { III } & \text { VI } & \text { VII } & \text { VIII } \\
\mathrm{P}_{1} & 1 & 1 & 1.5 & 1 & \phi \\
\mathrm{P}_{2} & 0.5 & 1.5 & 1.5 & 0 & \phi \\
\mathrm{P}_{3} & 1 & 0.5 & 1.5 & 0.5 & \phi \\
\mathrm{P}_{4} & 0 & 1 & 0.5 & 0.5 & 0 \\
\mathrm{P}_{5} & 1.5 & 2 & 0 & 0.5 & 0
\end{array}\right]
$$

Berdasarkan matriks penugasan pada langkah diatas, Nilai terendah yang tidak dilewati garis terdapat pada elemen $(1,2)$ yaitu bernilai 0.5 . Selanjutnya, nilai elemen-elemen yang tidak dilalui garis akan dikurangkan dengan nilai elemen $(1,2)$. Kemudian, nilai elemen-elemen yang melalui perpotongan garis seperti $(4,4),(4,5),(5,4)$ dan $(5,5)$ ditambahkan dengan nilai elemen $(2,1)$. Adapun untuk nilai elemen-elemen yang dilalui garis tetapi tidak terletak pada perpotongan baris nilainya tetap. Dengan demikian susunan matriks penugasannya menjadi:

$$
\mathrm{A}_{1}=\left[\begin{array}{cccccc} 
& \text { II } & \text { III } & \text { VI } & \text { VII } & \text { VIII } \\
\mathrm{P}_{1} & 0.5 & 0.5 & 1 & 1 & 0 \\
\mathrm{P}_{2} & 0 & 1 & 1 & 0 & 0 \\
\mathrm{P}_{3} & 0.5 & 0 & 1 & 0.5 & 0 \\
\mathrm{P}_{4} & 0 & 1 & 0.5 & 1 & 0.5 \\
\mathrm{P}_{5} & 1.5 & 2 & 0 & 1 & 0.5
\end{array}\right]
$$

Melakukan kembali pemeriksaan. Pemeriksaan dilakukan kembali seperti pada langkah sebelumnya. Dengan cara yang sama diperoleh hasil pemeriksaan sebagai berikut:

$$
\mathrm{A}_{1}=\left[\begin{array}{ccccccc} 
& \text { II } & \text { III } & \text { VI } & \text { VII } & \text { VIII } \\
\mathrm{P}_{1} & 0.5 & 0 & 5 & 1 & 1 & \phi \\
\mathrm{P}_{2} & 0 & 1 & 1 & 0 & \oint \\
\mathrm{P}_{3} & 0.5 & \oint & 1 & 0.5 & \oint \\
\mathrm{P}_{4} & 0 & 1 & 0.5 & 1 & 0.5 \\
\mathrm{P}_{5} & 1.5 & 2 & 0 & 1 & 0.5
\end{array}\right]
$$

Setelah ditarik garis seminimal mungkin, ternyata jumlah garis yang terbentuk sudah sama dengan jumlah baris atau kolom. Artinya, penyelesaian sudah optimal. Dengan demikian, solusi atau keputusan untuk matriks $A_{1}$ yaitu:
Berdasarkan hasil perhitungan setelah menggunakan metode Hungarian, diperoleh total waktu optimal untuk matriks $A_{1}$ sebesar 11 jam, dengan pengaturan penugasan yaitu Andy mengerjakan tugas menjahit celana kain dengan waktu penyelesaian 2 jam, Lily mengerjakat tugas menjahit celana jeans dengan waktu penyelesaian 2 jam, Eddy mengerjakan tugas menjahit jaket dengan waktu penyelesaian 3 jam, Adit mengerjakan tugas menjahit kaos polo dengan waktu penyelesaian 2 jam, dan Surya mengerjakan tugas menjahit kain bermotif batik dengan waktu penyelesaian 2 jam.

\begin{tabular}{ccc} 
Pekerja & Tugas & Waktu (jam) \\
\hline Pekerja 1 & VIII & 2 \\
Pekerja 2 & VII & 2 \\
Pekerja 3 & III & 3 \\
Pekerja 4 & II & 2 \\
Pekerja 5 & VI & 2 \\
\hline Total & & 11
\end{tabular}

Selanjutnya, untuk menyelesaikan matriks $\mathrm{A}_{2}$ sebagai matriks keseimbangan kedua sama seperti langkah-langkah menyelesaikan matriks $A_{1}$, yaitu sebagai berikut:

$$
A_{2}=\left[\begin{array}{cccc} 
& \text { I } & \text { IV } & \text { V } \\
P_{2} & 5 & 4 & 4 \\
P_{4} & 5 & 3 & 3 \\
P_{5} & 6 & 4 & 3
\end{array}\right]
$$

Menentukan nilai elemen terkecil pada setiap baris. Nilai elemen terkecil pada setiap baris dari matriks $\mathrm{A}_{2}$ adalah sebagai berikut:

$$
\mathrm{A}_{2}=\left[\begin{array}{cccc} 
& \mathrm{I} & \mathrm{IV} & \mathrm{V} \\
\mathrm{P}_{2} & 5 & 4 & 4 \\
\mathrm{P}_{4} & 5 & 3 & 3 \\
\mathrm{P}_{5} & 6 & 4 & 3
\end{array}\right]
$$

Kemudian, lakukan operasi pengurangan di tiap nilai pada baris tersebut dengan nilai terkecil yang telah dipilih.

$$
\mathrm{A}_{2}=\left[\begin{array}{cccc} 
& \mathrm{I} & \mathrm{IV} & \mathrm{V} \\
\mathrm{P}_{2} & 1 & 0 & 0 \\
\mathrm{P}_{4} & 2 & 0 & 0 \\
\mathrm{P}_{5} & 3 & 1 & 0
\end{array}\right]
$$

Memeriksa kolom untuk memastikan bahwa semua kolom sudah memiliki nilai nol.

$$
A_{2}=\left[\begin{array}{cccc} 
& \text { I } & \text { IV } & \text { V } \\
\mathrm{P}_{2} & 1 & 0 & 0 \\
\mathrm{P}_{4} & 2 & 0 & 0 \\
\mathrm{P}_{5} & 3 & 1 & 0
\end{array}\right]
$$


Setelah diperiksa, ternyata matriks pada langkah 2 menunjukkan bahwa kolom I masih belum terdapat nilai 0 . Oleh karena itu, semua nilai yang ada pada kolom tersebut akan dikurangi dengan nilai elemen terkecil pada kolom tersebut. Adapun elemen terkecil yang terdapat pada kolom I adalah 1. Sehingga diperoleh:

$$
A_{2}=\left[\begin{array}{cccc} 
& \text { I } & \text { IV } & \text { V } \\
\mathrm{P}_{2} & 0 & 0 & 0 \\
\mathrm{P}_{4} & 1 & 0 & 0 \\
\mathrm{P}_{5} & 2 & 1 & 0
\end{array}\right]
$$

Memeriksa apakah solusi sudah optimal dengan cara menarik garis secara vertikal atau horizontal. Adapun hasil pemeriksaannya sebagai berikut:

$$
A_{2}=\left[\begin{array}{llll} 
& I & I V & V \\
P_{2} & \phi & \phi & \phi \\
P_{4} & 1 & \phi & \phi \\
P_{5} & \& & 1 & \phi
\end{array}\right]
$$

Setelah ditarik garis seminimal mungkin, ternyata jumlah garis yang terbentuk sudah sama dengan jumlah baris atau kolom, yaitu sebanyak tiga garis. Artinya, penyelesaian sudah optimal. Dengan demikian, solusi atau keputusan untuk matriks $A_{2}$ yaitu:

Setelah menggunakan metode Hungarian, diperoleh total waktu optimal matriks $A_{2}$ sebesar $11 \mathrm{jam}$, dengan pengaturan penugasan yaitu Lily mengerjakan tugas menjahit jas dengan waktu penyelesaian 5 jam, Adit mengerjakan tugas menjahit pakaian dinas harian (PDH) dengan waktu penyelesaian 3 jam, dan Surya mengerjakan tugas menjahit kemeja sekolah dengan waktu penyelesaian 3 jam.

\begin{tabular}{ccc} 
Pekerja & Tugas & Waktu (jam) \\
\hline Pekerja 2 & I & 5 \\
Pekerja 4 & IV & 3 \\
Pekerja 5 & V & 3 \\
\hline Total & & 11
\end{tabular}

Total waktu optimal dari matriks $\mathrm{A}_{1}$ sebagai matriks keseimbangan pertama dan $\mathrm{A}_{2}$ sebagai matriks keseimbangan kedua setelah menggunakan Modified Hungarian method

\begin{tabular}{|c|c|c|}
\hline Pekerja & Jenis Pekerjaan & Waktu (jam) \\
\hline Pekerja 1 & VIII & 2 \\
\hline Pekerja 2 & VII, I & $2 ; 5$ \\
\hline Pekerja 3 & III & 3 \\
\hline Pekerja 4 & II, IV & $2 ; 3$ \\
\hline Pekerja 5 & VI, V & $2 ; 3$ \\
\hline
\end{tabular}
adalah sebagai berikut:

\section{KESIMPULAN DAN SARAN}

Sebelum menggunakan Modified Hungarian method, total waktu yang dibutuhkan para perkerja Mitra Tex Konveksi untuk mengerjakan seluruh jenis pekerjaan yang ada adalah sebesar 27,9 jam. Setelah menggunakan metode tersebut, hasilnya berubah menjadi 22 jam. Dapat dilihat terjadi efisiensi atau penghematan waktu sebanyak 5,9 jam. Hal ini menunjukkan bahwa sistem pembagian tugas karyawan yang tepat atau optimal dapat memberikan dampak terhadap kinerja perusahaan.

Efisiensi atau penghematan waktu sebesar 5,9 jam tersebut akan berdampak ketika Mitra Tex Konveksi menerima pesanan dari konsumen dalam jumlah banyak. Apabila hanya satu pesanan saja, penghematan waktu tersebut tidak terlalu berdampak. Efisiensi waktu ini berpengaruh pula terhadap sistem pembayaran gaji karyawan yang berlaku di Mitra Tex Konveksi. Mengingat kebijakan yang ada, semakin cepat atau semakin banyak seorang karyawan menyelesaikan pesanan konsumen, maka gaji atau upah yang mereka peroleh akan semakin banyak.

Adapun saran yang dapat disampaikan untuk penelitian selanjutnya adalah penelitian tentang metode Hungarian ini bisa dikembangkan menggunakan metode atau algoritma Brute Force.

\section{DAFTAR PUSTAKA}

Aminudin (2005). Prinsip-prinsip Riset Operasi. Jakarta: Erlangga.

Harini, D. (2017). Optimasi Penugasan Menggunakan Metode Hungarian pada

CV, L\&J Express Malang (Kasus Minimasi). Skripsi, Universitas PGRI Kediri.

Rabbani. (2019). Modified Hungarian Method for Unbalanced Assignment Problem with Multiple Jobs. Applied Mathematics and Computation Journal, 361, 493-498.

Syaifuddin, D. T. (2011). Riset Operasi (Aplikasi Quantitative Analysis for Management). Malang: CV Citra Malang.

Taha, A. H. (1997). Operation Research An Introduction. United States of America: Macmillan Publishing Company. 
E-Jurnal Matematika Vol. 10(1), Januari 2021, pp. 26-31

ISSN: 2303-1751

DOI: https://doi.org/10.24843/MTK.2021.v10.i01.p316 